\title{
Valuing scenic amenity using life satisfaction data
}

\author{
Christopher L. Ambrey ${ }^{1}$ and Christopher M. Fleming ${ }^{2}$
}

February 2011

\begin{abstract}
The life satisfaction approach has recently emerged as a new technique in the suite of options available to non-market valuation practitioners. Employing data from the Household, Income and Labour Dynamics in Australia (HILDA) survey and Geographic Information Systems (GIS), this paper examines the influence of scenic amenity on the life satisfaction of residents of South East Queensland (SEQ), Australia. Measuring scenic amenity on a 10-point scale, it is found that, on average, a respondent is willing-to-pay approximately AUD\$12,000 in household income per annum to obtain a one-unit improvement in scenic amenity. However, on closer inspection, we find that the relationship between willingness-to-pay and the level of scenic amenity is not linear. To our knowledge, this is the first paper to value scenic amenity using the life satisfaction approach and is the first paper to use this approach to value any type of environmental good or service in SEQ. As such, this paper represents a genuine contribution to a small, yet growing, body of literature.
\end{abstract}

Keywords: Geographic Information Systems (GIS); Happiness; Household, Income and Labour Dynamics in Australia (HILDA); Life Satisfaction; Non-market Valuation; Scenic Amenity.

JEL Classification: C21; I31; Q51; R10

This paper uses unit record data from the Household, Income and Labour Dynamics in Australia (HILDA) survey. The HILDA project was initiated and is funded by the Australian Government Department of Families, Housing, Community Services and Indigenous Affairs (FaHCSIA) and is managed by the Melbourne Institute of Applied Economic and Social Research (Melbourne Institute). The findings and views reported in this paper, however, are those of the authors and should not be attributed to either FaHCSIA or the Melbourne Institute.

\footnotetext{
${ }^{1}$ Department of Accounting, Finance and Economics, Gold Coast Campus, Griffith Business School, QLD 4222, Australia.

2 Department of Accounting, Finance and Economics, Nathan Campus, Griffith Business School, QLD 4111,

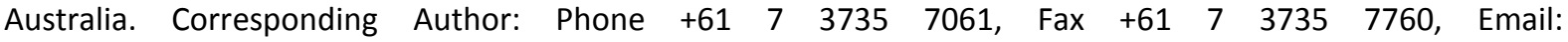
chris.fleming@griffith.edu.au.
} 


\section{Introduction}

The method and practise of placing monetary values on environmental goods and services for which a conventional market price is otherwise unobservable is one of the most fertile areas of research in the field of natural resource and environmental economics. Initially motivated by the need to include environmental values in benefit-cost analysis, practitioners of non-market valuation have since found further motivation in national account augmentation and environmental damage litigation.

By convention, valuation techniques are divided into two approaches. The revealed preference approach relies on observations about peoples' behaviour in markets that are someway related to the environmental good or service under consideration, while the stated preference approach uses surveys to question how respondents value that good or service. Techniques can be further divided into direct and indirect, depending upon whether a value is directly measured or inferred. Commonly used revealed preference techniques include hedonic pricing and the travel cost method, commonly used stated preference techniques include contingent valuation and choice modelling. An extensive review of the theory, methods and literature across a range of non-market valuation techniques and applications can be found in Freeman (2003).

Despite hundreds of applications and many decades of refinement, shortcomings in all of the techniques remain and no single technique is considered superior to the others in all respects. For example, authors who favour the use of revealed preference techniques generally point to the hypothetical nature of the stated preference approach, claiming that revealed preference techniques are superior because they are based on observations of actual behaviour and therefore not subject to strategic or other biases. Authors who favour the use of stated preference techniques point towards the increased flexibility (including the ability to measure non-use values) offered by this approach. Thus, techniques that expand the suite of options available to the non-market valuation practitioner have the potential to represent a genuine contribution to the field.

One technique to recently emerge is the 'life satisfaction approach'. Simply, this approach entails the inclusion of non-market goods as explanatory variables within microeconometric functions of life satisfaction along with income and other covariates. The 
estimated coefficient for the non-market good yields first, a direct valuation in terms of life satisfaction, and second, when compared to the estimated coefficient for income, the implicit willingness-to-pay for the non-market good in monetary terms (Frey et al., 2009).

The approach offers several advantages over more conventional non-market valuation techniques, particularly those used to value scenic amenity. For example, the approach does not rely on housing markets being in equilibrium (an assumption underpinning the hedonic property pricing method), nor does it ask individuals to directly value the non-market good in question (as is the case in contingent valuation and, to a lesser extent, choice modelling). Instead, individuals are asked to evaluate their general life satisfaction. This is perceived to be less cognitively demanding as specific knowledge of the good in question is not required, nor are respondents' asked to perform the unfamiliar task of placing a monetary value on a non-market good. Further, there is no reason to expect strategic behaviour or social desirability bias in relation to the good being valued (Welsch and Kuhling, 2009). ${ }^{3}$

The purpose of this paper is to use the life satisfaction approach to value scenic amenity in South East Queensland (SEQ). Although there is now a considerable literature on life satisfaction in economics, non-market valuation applications are comparatively rare. Thus, to the best of our knowledge, the paper will be the first to value scenic amenity using the life satisfaction approach in any region and the first to use this approach to value any type of environmental good or service in SEQ.

A review of the existing literature on the valuation of scenic amenity and the use of the life satisfaction approach to value environmental goods and services makes up the remainder of this Introduction. The paper then proceeds as follows. Section 2 outlines methodology, and includes a discussion of the measures of life satisfaction and scenic amenity employed. Results are presented in Section 3. Section 4 discusses and concludes.

\subsection{Valuing scenic amenity}

The role of natural environments as a source of scenic amenity has long been established. For example, the belief that viewing vegetation, water and other natural elements can

\footnotetext{
${ }^{3}$ There is however, some evidence that social desirability bias exists in the form of respondents reporting higher levels of life satisfaction when interviewed in the presence of others, see: Ambrey, C., Fleming, C., 2011. The influence of the natural environment and climate on life satisfaction in Australia, Griffith University Discussion Paper in Economics and Business Statistics No. 2011-01, Brisbane.
} 
ameliorate stress and is beneficial for patients in healthcare environments dates as far back as the earliest large cities in Persia, China and Greece (Velarde et al., 2007). While the impact of natural environments on human well-being is clearly broader than the provision of scenic amenity, vision is by far our most important sense in terms of yielding information about outdoor environments (Ulrich, 1979). Moreover, a significant part of the satisfaction derived from nature does not require being in the natural setting, but rather having a view of it (Velarde et al., 2007).

There is a substantial body of literature seeking to establish the monetary value of scenic amenity. The hedonic property pricing method, where the value of the scenic amenity is inferred from its impact on property values, predominates. In an early example, Gillard (1981) uses the hedonic pricing method to investigate the effect of views on the value of homes in the Los Angeles metropolitan area. The author employs a simple dummy variable and finds that being situated on a lot with a view has a positive and significant influence on a property's selling price. Later studies (cf. Benson et al., 1998; Jim and Chen, 2009; Samarasinghe and Sharp, 2010) employ more comprehensive definitions of 'view', differentiating between type (for example, ocean, lake or mountain) and scope (unobstructed or partial). Almost without exception, scenic views (particularly ocean views) are found to have a positive and significant influence on residential property values.

There are a number of hedonic pricing studies seeking to value scenic amenity in an Australian context. McLeod (1984), investigating the importance of local amenities in Perth, Western Australia, finds river views to have a particularly strong positive influence on selling price. Also in Western Australia, Fraser and Spencer (1998) find that an ocean view contributes up to 25 per cent of the value of undeveloped residential land in a coastal housing subdivision. Pearson et al. (2002) use the hedonic pricing method to estimate the impact of Noosa National Park, Queensland, on surrounding properties. The authors find that while a view of the National Park increases property values (by approximately seven per cent), access to the National Park does not. Distance to, and views of, the ocean however, have a far greater impact than any of the variables associated with the National Park. While not directly considering scenic amenity, Tapsuwan et al. (2009) use hedonic pricing to value the amenity value of Perth's urban wetlands. The authors find that properties with wetland frontage attract a significant sales premium, with values declining 
rapidly with distance. The authors posit that this could be related to the convenience of easy walking access to the wetland; however it seems plausible that visual amenity would also be a contributing factor.

There are a small number of studies that use alternative non-market valuation techniques to place a monetary value on scenic amenity. In a seminal contribution, Randall et al. (1974) use the contingent valuation method to place values on aesthetic environmental improvements. Willis and Garrod (1993) use the same method to elicit preference for, and values of, alternative future landscapes in the Yorkshire Dales National Park, as do Groothius et al. (2007) to measure the amount citizens are willing-to-pay to improve scenic mountainview amenities through the removal of billboards in an area surrounding the Appalachian Mountains. Bienabe and Hearne (2006) use another stated preference method, choice modelling, to investigate the willingness of foreign tourists and residents to support enhanced nature conservation and scenic amenity in Costa Rica. The authors find that, while support is greatest for projects that enhance nature conservation, both groups nonetheless indicate a significant and positive willingness-to-pay to improve scenic amenity.

\subsection{Life satisfaction in economics}

Research into life satisfaction (or happiness) is increasingly the foci of a great deal of empirical investigation in economics. This research has been motivated, at least in part, by dissatisfaction with traditional means of measuring economic progress, as clearly evidenced by the findings of the Commission on the Measurement of Economic Performance and Social Progress (Stiglitz et al., 2008). This area of research also reflects a broader reevaluation of the epistemological foundations of economics, as seen in 2002 by Daniel Kahneman (a psychologist) and Vernon Smith (the pioneer of experimental economics) together being awarded the Nobel Prize in economic sciences.

At an individual level, a great deal of effort has been devoted to better understanding the drivers of life satisfaction, with a number of stylised 'facts' becoming apparent. For example, a common finding is that men are less happy than women (cf. Blanchflower and Oswald, 2004b), although the difference is not great and some recent studies have found the reverse to be true (cf. Ambrey and Fleming, 2011). Age is U-shaped, with happiness reaching a minimum in a person's 30s and 40s; a relationship found to be robust, even once cohort 
effects and other socio-demographic factors are controlled for (cf. Blanchflower and Oswald, 2004a; Blanchflower and Oswald, 2004b, 2008, 2009).

The impact of income on life satisfaction is overwhelmingly positive, although the coefficient is typically not large. Marriage is found to improve life satisfaction (cf. Ambrey and Fleming, 2011; Evans and Kelley, 2004). However, Blanchflower and Oswald (2004b), Evans and Kelley (2004) and Gray et al. (2010) find second and subsequent marriages appear to be less happy than first marriages. Evidence on the effect of children is mixed, although recent evidence suggests life satisfaction decreases as the number of dependent children increases (cf. Ambrey and Fleming, 2011; Margolis and Myrskyla, 2010). Poor health invariably lowers life satisfaction, as does unemployment (Frijters et al., 2004a, b). In developed countries, education appears to have a negative influence on life satisfaction, whereas in developing countries the reverse is true (Veenhoven, 1996). Many studies have found that happiness is greater for those who are more religious (cf. Blanchflower and Oswald, 2004b; Graham et al., 2004). A comprehensive review of life satisfaction in economics is provided by Frey and Stutzer (2002).

\subsubsection{Valuing environmental amenities using life satisfaction data}

A small, but growing, body of literature suggests that external influences, in particular natural environments, are key drivers of life satisfaction (cf. Ambrey and Fleming, 2011; Brereton et al., 2008; Smyth et al., 2008). It is from this literature that the life satisfaction approach to non-market valuation has developed. In an early example of the approach being used in practise, Welsch (2002) uses cross-section data on reported well-being for 54 countries to value urban air pollution. The author finds that, on average, an individual needs to be given USD\$70 per annum compensation in order to accept a one-kiloton per capita increase in urban nitrogen dioxide load. While the valuation of air quality has dominated the literature (cf. Ferreira and Moro, 2010; Luechinger, 2009; MacKerron and Mourato, 2009; Welsch, 2006; Welsch, 2007), other non-market environmental goods valued via the life satisfaction approach include airport noise (cf. van Praag and Baarsma, 2005), climate (cf. Ferreira and Moro, 2010; Frijters and van Praag, 1998; Rehdanz and Maddison, 2005), species diversity (cf. Rehdanz, 2007) and floods (cf. Luechinger and Raschky, 2009). ${ }^{4}$ In the

\footnotetext{
${ }^{4}$ A review of many of these studies can be found in: Welsch, H., Kuhling, J., 2009. Using happiness data for environmental valuation: Issues and applications. Journal of Economic Surveys 23, 385-406.
} 
only previous Australian study, Carroll et al. (2009) use life satisfaction data to estimate the cost of drought. The authors find that while drought imposes no significant cost on urban residents, a drought in spring has a detrimental effect on rural residents equivalent to an annual reduction in income of AUD\$18,000.

It is important to acknowledge that the life satisfaction approach values only the residual benefits (or costs) of the non-market good not captured in housing or labour markets (Luechinger, 2009; van Praag and Baarsma, 2005). When valuing scenic amenity, the approach should thus be regarded as a complement to, rather than a substitute for, the hedonic property pricing method. If the assumption of equilibrium in the housing market holds, then no relationship should exist between scenic amenity and life satisfaction, because housing costs would fully adjust to compensate. If however a significant relationship is found, then residual benefits must remain. The value of scenic amenity is thus the sum of any amenity-related housing costs plus the benefits estimated via the life satisfaction approach.

\subsection{South East Queensland}

The case study area, SEQ, is a region of the state of Queensland in Australia. The region covers 22,240 square kilometres, extending 240 kilometres from Noosa in the north to the Gold Coast / New South Wales border in the south and 140 kilometres west to Toowoomba (Figure 1). The region has experienced rapid population growth over the previous two decades, and the population is projected to increase by 44 per cent to 4.4 million by 2031 (Office of Economic and Statistical Research, 2010). In 2007 Brisbane City, the principle urban centre of SEQ, was the second fastest growing urban centre in the developed world (Newman, 2007). Such rapid population growth has necessarily lead to rapid increases in the built environment, often at the expense of the natural environment from which most scenic amenity is derived. Further, the current SEQ Regional Plan promotes increased residential density as a solution to population pressures. Despite objections from residents, and in some cases the State Government, local government is allowing infill and high-rise housing to be developed in previously low-density resident suburbs (cf. Vogler, 2010). Moreover,

under local planning regulations, obstruction of views is not usually considered valid grounds for contesting a development proposal (Queensland Department of Infrastructure 
and Planning, 2009). Declining scenic amenity is therefore an issue of particular importance to the region.

\section{[Insert Figure 1 here]}

\section{Method and data}

Following the notation of Brereton et al. (2008), the life satisfaction model takes the form of an indirect utility function for individual $i$ in location $k$ as follows:

$$
U_{i, k}=\alpha+\beta_{1} \ln \left(y_{i, k}\right)+\beta_{2} x_{i . k}+\beta_{3} a_{i, k}+\varepsilon_{i . k} \quad i=1 \ldots I, k=1 \ldots K
$$

Where $y_{i, k}$ is household income, $x$ is a vector of socio-economic and demographic characteristics including age, marital status, employment status, education and so forth, and $a_{i, k}$ is a spatially weighted average measure of scenic amenity for the collection district $(C D)^{5}$ in which the respondent resides. In the micro-econometric function, the individual's true utility is unobservable; hence self-reported life satisfaction is used as a proxy.

It is possible to estimate the willingness-to-pay (denoted WTP) for a marginal change in scenic amenity by taking the partial derivative of scenic amenity and the partial derivative of the natural log of household income, as follows:

$W T P=\frac{\frac{\partial a_{i, k}}{\partial U}}{\frac{\partial \ln \left(y_{i, k}\right)}{\partial U}}=\frac{\partial a_{i, k}}{\partial \ln \left(y_{i, k}\right)}=\bar{y} \frac{\widehat{\beta_{3}}}{\widehat{\beta_{1}}}$

Where $\bar{y}$ is the mean value of household income. ${ }^{6}$ If non-marginal changes are to be valued, the Hicksian welfare measures of compensating and equivalent surplus can be employed. In this case, the compensating surplus is the amount of household income an individual would need to receive (pay) following a deterioration (improvement) in the level of scenic amenity in his or her $C D$, in order to remain at his or her initial level of utility. Compensating surplus (denoted CS) can be calculated as follows:

$C S=-\exp \left[\overline{\ln (y)}+\frac{\widehat{\beta_{3}}}{\widehat{\beta_{1}}}\left(a^{1}-a^{2}\right)\right]+\bar{y}$

\footnotetext{
${ }^{5}$ The CD is the spatial base unit used to collect and disseminate statistics other than those collected from the Population Censuses. Australian Bureau of Statistics, 2010. Australian Standard Geographical Classification, Catalogue No. 1216.0, Canberra.

${ }^{6}$ To obtain $\bar{y}$, the mean value of the natural log of household income from the sample is 10.80696 , which corresponds to a mean household income of \$49.363.18.
} 
Where $a^{1}$ is the initial, and $a^{2}$ the new, amenity value. Similarly, the equivalent surplus is the amount of household income an individual would need to receive or pay in order to obtain the level of utility following a change, if the change did not take place. Equivalent surplus (denoted ES) can be calculated as follows:

$E S=\exp \left[\overline{\ln (y)}+\frac{\widehat{\beta_{3}}}{\widehat{\beta_{1}}}\left(a^{2}-a^{1}\right)\right]-\bar{y}$

Having valued the non-market good, the assumption of diminishing marginal utility of income and, consequently, increasing marginal willingness-to-pay, implied in the natural log transformation of household income can be tested (Frey et al., 2009; Levinson, 2009). This is achieved through the inclusion of an interaction between the natural log of household income and scenic amenity, as shown in Equation 5:

$U_{i, k}=\alpha+\beta_{1} \ln \left(y_{i, k}\right)+\beta_{2} x_{i . k}+\beta_{3} a_{i, k}+\beta_{4} a_{i, k}\left(\ln \left(y_{i, k}\right)-\widetilde{\ln (y)}\right)+\varepsilon_{i . k}$

Where $\beta_{4}$ is the coefficient of the interaction term and $\widetilde{\ln (y)}$ is the median natural log of household income. Our a priori expectation is that the interaction term will be statistically significant and positive for utility, or more specifically our proxy, life satisfaction. This would suggest individuals with a household income higher than the median are willing-to-pay more for enhanced scenic amenity and those with a lower income, willing-to-pay less. This assumption can be further tested by comparison of the willingness-to-pay of individuals from different household income percentiles, as follows:

$W T P=\frac{\frac{\partial a_{i, k}}{\partial U}}{\frac{\partial \ln \left(y_{i, k}\right)}{\partial U}}=\frac{\partial a_{i, k}}{\partial \ln \left(y_{i, k}\right)}=\bar{y} \frac{\left[\widehat{\beta_{3}}+\widehat{\beta_{4}}(\ln (y)-\overparen{\ln (y)})\right]}{\left[\widehat{\beta_{1}}+\widehat{\beta_{4}} \bar{a}\right]}$

Where $y$ is the income of the percentile under consideration.

\subsection{Household, Income and Labour Dynamics in Australia}

The measure of self-reported life satisfaction and the various internal socio-economic and demographic characteristics are obtained from the HILDA survey. The HILDA survey was conceived by the Australian Government Department of Families, Housing, Community Services and Indigenous Affairs and was developed with the aim of supporting research and policy questions within the areas of: family and household dynamics; income and welfare dynamics; and labour market dynamics (Wooden and Watson, 2007). First conducted in 2001, by international standards the HILDA survey is a relatively new nationally 
representative sample and owes much to other household panel studies conducted elsewhere in the world; particularly the German Socio-Economic Panel and the British Household Panel Survey. For a review of household panel datasets throughout the world see Haisken-DeNew (2001) and for a recent review of progress and future developments of the HILDA survey see Watson and Wooden (2010).

The life satisfaction variable is obtained from individuals' responses to the question: 'All things considered, how satisfied are you with your life?' The life satisfaction variable is an ordinal variable, the individual choosing a number between 0 (totally dissatisfied with life) and 10 (totally satisfied with life).

Behind the answers to happiness or life satisfaction questions lies a cognitive assessment of to what extent the respondent's overall quality of life is judged in a favourable way (Veenhoven, 1993). Schwarz and Strack (1991) point out that these judgements by the individual are often partially dependent on transient influences, such as one's mood. Hence these self-reported measures of life satisfaction are sometimes designated 'avowed' or 'reported' life satisfaction to infer that they may not reflect the true state of a respondent's feelings (Easterlin, 1974).

While not without its critics (cf. Smith, 2008), there is much evidence to support the objectivity and comparability of individual's responses to life satisfaction questions, with individual self-reports of life satisfaction (or happiness) being highly correlated with reports by others, as well as with physical measurements of brain electro-encephelograms (EEGs) and smiling behaviour (cf. Diener and Suh, 2000). The literature also finds support in evidence of happy people being rated as such by family, friends and spouses (cf. Costa and McCrae, 1988; Lepper, 1998; Sandvik et al., 1993). Reliability studies indicate that measurements of life satisfaction are stable and sensitive to life events (cf. Sandvik et al., 1993). Consistency tests reveal happy people smile more often during social interactions (cf. Fernandez-Dols and Ruiz-Belda, 1995) and are less likely to commit suicide (cf. KoivumaaHonkanen et al., 2001). In all, according to $\mathrm{Ng}$ (2008) despite the many conceptual and measurement issues, there are persuasive arguments that existing measures of life satisfaction, though imperfect, are rather reliable.

The inclusion of explanatory variables within the model was guided by the existing literature, data availability, and assisted to a limited degree by SAS model selection tools. 
One estimation issue identified by Ferrer-i-Carbonell and Frijters (2004), is that the treatment of time-invariant unobserved factors is critical to the validity of results. Specifically, the error term captures measurement errors as well as unobserved characteristics. Thus, results can be obscured by personality traits that aren't taken into account (Bertrand and Mullainathan, 2001; Ravallion and Lokshin, 2001). It is possible however for idiosyncratic effects, such as those caused by personality traits, to be controlled for if the same individuals are resurveyed over time, that is, if they are taken to be timeinvariant (Ferrer-i-Carbonell and Frijters, 2004; Frijters et al., 2006; Frijters et al., 2004a, b).

To control for personality traits, this paper opts for a parsimonious approach, employing a cross section of the HILDA survey data, Wave 5. Extending the efforts of Shields et al. (2009) and Gray et al. (2010) an attempt is made to capture the heterogeneity that arises from differences in personality through the inclusion of additional variables, namely: extraversion; agreeableness; conscientiousness; emotional stability; and openness to experience, the so-called taxonomic 'Big Five' (Saucier, 1994). Social desirability bias is also controlled for by the inclusion of a variable indicating whether or not the individual was interviewed in the presence of another person.

\subsection{Scenic amenity}

The measure of scenic amenity employed in this paper was developed as part of the SEQ Regional Scenic Amenity Study (2005). This study was initiated by the Local Governments of SEQ through the SEQ Regional Organisation of Councils, the Queensland Government, SEQ Natural Resource bodies and SEQWater. The study's objective was to identify the most valued scenic areas in SEQ, based on public opinion, and to develop context-appropriate guidelines for assessing the influence of development near these scenic areas. ${ }^{7}$

As outlined in Figure 2, the assessment of scenic amenity was divided into two stages. The first stage involved a public preference survey to identify the characteristics of views that influence people's preferences for scenery. The second assessment stage used these survey data to prepare maps that show the location of areas with highly preferred scenery through to areas of least preferred scenery. Scenic preference maps were then combined with maps

\footnotetext{
${ }^{7}$ For further information about the SEQ Regional Scenic Amenity Study, see: http://pandora.nla.gov.au/pan/53524/20051229-0000/www.scenicseq.info/default.html.
} 
showing the degree of visibility of the landscape to produce maps of scenic amenity on a scale from 1 to 10 (SEQ Regional Scenic Amenity Study, 2005).

\section{[Insert Figure $\mathbf{2}$ here]}

This measurement of scenic preference is based on the Scenic Beauty Estimation technique developed by the United States Department of Agriculture (Daniel and Boster, 1976). The fundamental survey task was to ask respondents to 'Rate each view along a scale from views you like most to views you like least'. Similar survey techniques have been used to assess people's visual preference in different contexts and for various planning applications, such as to record and map view preferences in urban environments (cf. Bishop et al., 2004), to assess the visual impact of wind turbines (cf. Bishop, 2002) and to record the impact of signs in urban environments (cf. Nasar and Hong, 1999). Unlike terms such as landscape character (Brodbeck, 2005; Swanwick, 2002) scenic amenity, as defined, does not profess to reflect cultural, historical, geological or environmental factors, nor aesthetic, scenic or landscape quality, except to the extent that these factors influence public preference for scenery (SEQ Regional Scenic Amenity Study, 2005).

The scenic amenity score is created using ArcGIS and is the spatially weighted average of scenic amenity for the CD. This variable is linked to respondents in the HILDA survey. All of the explanatory variables included within the model are summarised in Table 1.

\section{[Insert Table 1 here]}

\section{Results}

Two techniques are employed in model estimation, ordinary least squares (OLS) and ordered probit by maximum likelihood estimation. This is similar to the estimation strategies employed by Brereton et al. (2008), Shields et al. (2009) and Smyth et al. (2008). Other estimation options include the binary probit or logit models (cf. Winklemann and Winklemann, 1998) and the ordered logit model (cf. MacKerron and Mourato, 2009).

In terms of evaluating the appropriateness of the estimation strategy, it is important to consider whether life satisfaction self-reports are assumed to be ordinal or cardinal. If assumed to be cardinal, then the coefficients obtained via OLS are biased and inconsistent, in which case the use of an ordered probit model is more appropriate (Hill et al., 2008). However, many authors (cf. Ferrer-i-Carbonell and Frijters, 2004) have shown that estimates 
of the determinants of life satisfaction are virtually unchanged whether one models the ordinal nature of the variable (as implied by the use of ordered probit) or treats the responses as cardinal (implied by the use of OLS), contingent on individual heterogeneity being addressed appropriately.

In order to account for location-specific effects, the regression of aggregate explanatory variables on a disaggregated dependent variable, and the consequences of complex survey design, robust standard errors need to be adjusted for clustering. In this case, standard errors are adjusted at the CD level, the highest level at which intra-cluster correlation in errors may be a problem. (Cameron and Trivedi, 2010; Moulton, 1986, 1990; Nichols and Schaffer, 2007).

\section{1. $\quad$ Model results}

The estimated results for Equation 1 are presented in Tables 2A (OLS) and 2B (ordered probit). As expected, the results do not differ greatly between the two estimation techniques. The explanatory power of the OLS estimation, as measured by an adjusted $R^{2}$ of 0.1518 , and of the ordered probit estimation, as measured by a pseudo $R^{2}$ of 0.0572 , is comparable to other studies of this type (cf. Shields et al., 2009).

In regards to socio-economic and demographic characteristics, the results largely support the existing literature and a priori expectations. That is, life satisfaction is U-shaped in age, reaching a minimum at the age of 37. As also reported by Shields et al. (2009) and Ambrey and Fleming (2011) respondents of Aboriginal and/or Torres Strait Islander origin are found to be more satisfied with their lives than the general population. Immigrants from English speaking countries are found to be less satisfied than the native born. In terms of marital status, only being separated is found to have a statistically significant negative effect on life satisfaction.

As is consistent with the literature (cf. Ambrey and Fleming, 2011; Shields et al., 2009; Wooden et al., 2009), having a long-term health condition is associated with lower levels of life satisfaction, with the greatest impact felt by those with a severe health condition. With regards to education, having completed Year 12 (final year of schooling) is found to have a positive impact on life satisfaction compared to having only obtained an education up to 
Year 11; a finding reinforced by existing studies (cf. Brereton et al., 2008; Moro et al., 2008). Having a higher level of education has no significant impact on life satisfaction.

In terms of employment status, being employed part-time or being retired are both associated with higher levels of life satisfaction than working full-time. The positive effect of being employed part-time is consistent with other Australian studies (cf. Shields et al., 2009; Shields and Wooden, 2003), although is in stark contrast to studies elsewhere (cf. Brereton et al., 2008; Moro et al., 2008). Undertaking home duties is found to have a positive impact on life satisfaction in the ordered probit estimation, but is insignificant when the model is estimated using OLS. As expected, higher levels of household income are found to be associated with higher levels of life satisfaction.

The use of personality trait controls substantially increases the explanatory power in both the OLS and ordered probit models (by $46 \%$ and $51 \%$ respectively). The results show that three of the Big Five personality trait variables are statistically significant at the one per cent level, with higher degrees of extraversion, agreeableness and emotional stability all associated with higher levels of life satisfaction; these results are in keeping with DeNeve and Cooper (1998). In contrast to much of the literature (cf. Ambrey and Fleming, 2011; Shields et al., 2009; Wooden et al., 2009), there is no evidence of social desirability bias, with others being present during the interview having no significant effect on self-reported life satisfaction. Moreover, unlike previous studies (cf. Ambrey and Fleming, 2011; Brereton et al., 2008; Smyth et al., 2008), living in a major city is not found to have a significant impact on life satisfaction. Finally, of particular importance to this study, the spatially weighted average of the scenic amenity scores for the $C D$ in which the respondent lives is found to have a positive and significant effect on life satisfaction.

\section{[Insert Tables 2A and 2B here]}

\subsubsection{Valuing scenic amenity}

Following the procedure described in Equation 2, the average willingness-to-pay in terms of annual household income, for a one-unit improvement in scenic amenity, is $\$ 12,673.81$ and $\$ 14,699.92$ for the OLS and ordered probit estimations respectively (see Table 3$).{ }^{8}$ Given, on

\footnotetext{
${ }^{8}$ Unless otherwise stated, all figures are in AUD. As at 25 January 2011 AUD \$1 $=0.73$ EUR.
} 
average, there are 2.5 people living in each household in the sample, this implies a percapita willingness-to-pay of approximately $\$ 5,500$.

Similarly, a one standard deviation (1.430299) improvement in scenic amenity from the mean yields a compensating surplus of $\$ 15,171.55$ (OLS) or $\$ 17,121.05$ (ordered probit), thus suggesting, following such an improvement, an individual is able to sacrifice approximately $\$ 16,000$ in annual household income and remain at the initial level of utility. The comparable equivalent surplus estimates are $\$ 21,903.49$ (OLS) and $\$ 26,212.59$ (ordered probit), suggesting an individual would require an increase in annual household income of $\$ 23,000$ for such an improvement not to occur.

\section{[Insert Table 3 here]}

Having undertaken the valuation of scenic amenity in SEQ, we subsequently test the assumption of diminishing marginal utility of household income. Following the procedures set out in Equations 5 and 6, the willingness-to-pay of individuals' with household income in the $25^{\text {th }}, 50^{\text {th }}$ (median) and $75^{\text {th }}$ percentiles are compared (Table 4). ${ }^{9}$ As expected, households with higher incomes are found to be willing-to-pay more for improvements in scenic amenity. Specifically, the OLS estimation suggests that an individual with a household income in the $25^{\text {th }}$ percentile is willing-to-pay $\$ 9,614.78$ for a one-unit increase in scenic amenity, an individual with the median household income $\$ 13,689.41$ and an individual with a household income in the $75^{\text {th }}$ percentile, $\$ 16,305.57$. For the ordered probit estimation, the values are $\$ 11,196.48, \$ 15,870.42$ and $\$ 18,871.38$ respectively. These results provide further confirmatory evidence (cf. Levinson, 2009) that environmental quality, including scenic amenity, is a normal good and that diminishing marginal utility of income is a sound assumption.

\section{[Insert Table 4 here]}

\subsubsection{Marginal return from increases in scenic amenity}

Implied in all of the valuation estimates presented above, is the assumption that scenic amenity exhibits a constant and linear relationship with an individual's life satisfaction. That

\footnotetext{
${ }^{9}$ While the interaction term $\left(\widehat{\beta_{4}}\right)$ in Equation 5 is not statistically significant, the two terms $\left(\widehat{\beta_{3}}\right)$ and $\left(\widehat{\beta_{4}}\right)$ are jointly significant (Prob. $>F=0.0872$ according to the OLS estimation and Prob $>\chi^{2}=0.0660$ according to the ordered probit estimation). This is similar to: Levinson, A., 2009. Valuing public goods using happiness data: The case of air quality, National Bureau of Economic Research Working Paper No. 15156, Washington DC.
} 
is, independent of the current level of scenic amenity, an improvement of an additional increment has the same effect on utility. Intuitively, this assumption seems questionable.

In order to evaluate if there is any variation in the marginal influence of scenic amenity on life satisfaction, we disaggregate the scenic amenity variable into five categories (very low, low, medium, high and very high, (see Table 1 for definitions)). Following this disaggregation, Equation 1 is re-estimated (see Table 5 for scenic amenity coefficients and summary statistics). ${ }^{10}$ Not only are all of the disaggregated scenic amenity variables statistically significant, the model's explanatory power is also improved. Moreover, the fact that the coefficients increase in size as scenic amenity improves, suggests that the assumption of a linear relationship between scenic amenity and life satisfaction is unfounded.

\section{[Insert Table 5 here]}

As shown in Table 6, the disaggregated variables yield some interesting results in terms of willingness-to-pay to move from one level of scenic amenity to another. Specifically, the estimates suggest a high willingness-to-pay (in terms of annual household income) to move from a very low level to a low level of scenic amenity $(\$ 92,667.93$ and $\$ 88,953.42$ for the OLS and ordered probit estimates respectively). From this point however, the willingness-topay to move to a medium level of scenic amenity is comparatively low $(\$ 3,778.29$ (OLS) and $\$ 847.28$ (ordered probit)), as is the willingness-to-pay to move from a medium to a high level of scenic amenity $(\$ 8,224.30$ (OLS) and $\$ 11,568.29$ (ordered probit)). In contrast, yet consistent with the willingness-to-pay to move from a very low to low level of scenic amenity, the willingness-to-pay to move from a high to a very high level of scenic amenity (a scenic amenity score of greater than eight) is very large $(\$ 108,418.17$ and $\$ 95,703.50$ for the OLS and ordered probit estimates respectively).

\section{[Insert Table 6 here]}

\section{Discussion}

This paper set out to employ the comparatively underutilised life satisfaction approach to place a monetary value on scenic amenity in SEQ, in so doing, extending a very small body of

\footnotetext{
${ }^{10}$ There were no significant changes to the other explanatory variables. Full model results are available from the authors on request.
} 
literature in this area. Our results, which find substantial values associated with improvements in scenic amenity, provide supporting evidence to the existing literature employing more traditional non-market valuation techniques.

Specifically, we find that improvements in scenic amenity have a positive and significant effect on life satisfaction, and that, on average, an individual is willing-to-pay approximately $\$ 12,000$ in annual household income for a one-unit improvement in scenic amenity, where scenic amenity is measured on a 10-point scale. Moreover, consistent with the assumption of diminishing marginal utility of income, we find this willingness-to-pay increases as household income increases.

Interestingly, the results indicate a non-linear relationship between improvements in scenic amenity and life satisfaction. Specifically, the results show initial improvements in scenic amenity from a very low level to be associated with a willingness-to-pay in the order of $\$ 88,953.42$ to $\$ 92,667.93$, depending upon the estimation strategy employed. Subsequent improvements from low to medium or medium to high levels of scenic amenity are associated with much lower values, in the order of $\$ 847.28$ to $\$ 11,568.29$. However, further improvements are again more highly valued, with willingness-to-pay estimates ranging from $\$ 95,703.50$ to $\$ 108,418.17$. These disaggregated estimates differ greatly from the average estimate of $\$ 12,000$, suggesting disaggregation yields additional insight into the relationship between scenic amenity and life satisfaction.

From a theoretical perspective, these value estimates point towards a substantial residual shadow value associated with scenic amenity that is not captured in housing costs. Consistent with earlier life satisfaction valuation literature (cf. Luechinger, 2009; van Praag and Baarsma, 2005), this finding challenges the validity of the assumption of equilibrium in housing markets, which underpins the hedonic property pricing method. Thus, these results provide further support for the use of the life satisfaction approach as a complement to the hedonic method when attempting to value non-market goods such as scenic amenity.

At an applied level, these estimates indicate that scenic amenity is highly valued by residents and that the preservation, or improvement, of existing levels of scenic amenity is of great importance. The challenge for policy makers and urban planners is to manage the pressures of projected population growth in rapidly growing regions. Finally, these results 
should encourage further research at a theoretical and applied level into the life satisfaction approach to non-market valuation. 


\section{Acknowledgements}

We thank Griffith University Business School for the Griffith Business School Honours Scholarship funding which was instrumental in facilitating this research. Additionally, this research would not have been possible without the data provided by the Australian Government Department of Families, Housing, Community Services and Indigenous Affairs (FaHCSIA), the Office of Urban Management, the Department of Infrastructure and Planning, Queensland and Australian Bureau of Statistics. 


\section{References}

Ambrey, C., Fleming, C., 2011. The influence of the natural environment and climate on life satisfaction in Australia, Griffith University Discussion Paper in Economics and Business Statistics No. 2011-01, Brisbane.

Australian Bureau of Statistics, 2010. Australian Standard Geographical Classification, Catalogue No. 1216.0, Canberra.

Benson, E., Hansen, J., Schwartz, A., Smersh, G., 1998. Pricing residential amenities: The value of a view. Journal of Real Estate Finance and Economics 16, 55-73.

Bertrand, M., Mullainathan, S., 2001. Do people mean what they say? Implications for subjective survey data. The American Economic Review 91, 67-72.

Bienabe, E., Hearne, R., 2006. Public preferences for biodiversity conservation and scenic beauty within a framework of environmental service payments. Forest Policy and Economics 9, 335-348.

Bishop, I., 2002. Determination of thresholds of visual impact: The case of wind turbines. Environment and Planning B 29, 707-718.

Bishop, I., Lange, E., Mahbubul, A., 2004. Estimation of the influence of view components on high-rise apartment pricing using a public survey and GIS modelling. Environment and Planning B 31, 439452.

Blanchflower, D., Oswald, A., 2004a. Money, sex and happiness: An empirical study. Scandinavian Journal of Economics 106, 393-415.

Blanchflower, D., Oswald, A., 2004b. Well-being over time in Britain and the USA. Journal of Public Economics 88, 1359-1386.

Blanchflower, D., Oswald, A., 2008. Hypertension and happiness across nations. Journal of Health Economics 27, 218-233.

Blanchflower, D., Oswald, A., 2009. The U-shape without controls: A response to Glenn. Social Science \& Medicine 69, 486-488.

Brereton, F., Clinch, J., Ferreira, S., 2008. Happiness, geography and the environment. Ecological Economics 65, 386-396.

Brodbeck, S., 2005. A view for the public. Australian Planner 42, 47-51.

Cameron, A., Trivedi, P., 2010. Microeconometrics Using Stata. Stata Press, College Station, Texas.

Carroll, N., Frijters, P., Shields, M., 2009. Quantifying the costs of drought: New evidence from life satisfaction data. Journal of Population Economics 22, 445-461.

Costa, P., McCrae, R., 1988. Personality in adulthood: A six-year longitudinal study of selfreports and spouse ratings on the NEO personality inventory. Journal of Personality and Social Psychology 54, 853-563.

Daniel, T., Boster, R., 1976. Measuring landscape aesthetics: The scenic beauty estimation method, United States Department of Agriculture Forest Service Research Paper RM-167, Fort Collins. 
DeNeve, K., Cooper, H., 1998. The happy personality: A meta-analysis of 137 personality traits and subjective well-being. Psychological Bulletin 124, 197-229.

Diener, E., Suh, E., 2000. Subjective Well-being Across Cultures. MIT Press, Cambridge, MA.

Easterlin, R., 1974. Does economic growth improve the human lot? Some empirical evidence, in: David, P., Redler, M. (Eds.), Nations and Households in Economic Growth: Essays in Honor of Moses Abramovitz. Academic Press, New York, pp. 89-125.

Evans, M., Kelley, J., 2004. Effect of family structure on life satisfaction: Australian evidence. Social Indicators Research 69, 303-349.

Fernandez-Dols, J., Ruiz-Belda, M., 1995. Are smiles a sign of happiness? Gold medal winners at the Olympic games. Journal of Personality and Social Psychology 69, 1113-1119.

Ferreira, S., Moro, M., 2010. On the use of subjective well-being data for environmental valuation. Environmental \& Resource Economics 46, 249-273.

Ferrer-i-Carbonell, A., Frijters, P., 2004. How important is methodology for the estimates of the determinants of happiness? The Economic Journal 114, 641-659.

Fraser, R., Spencer, G., 1998. The value of an ocean view: An example of hedonic property amenity valuation. Australian Geographical Studies 36, 94-98.

Freeman, A., 2003. The Measurement of Environmental and Resource Values: Theory and Methods, (second edition) ed. Resources for the Future, Washington DC.

Frey, B., Luechinger, S., Stutzer, A., 2009. The life satisfaction approach to environmental valuation, Discussion Paper No. 4478. Institute for the Study of Labor (IZA), Bonn.

Frey, B., Stutzer, A., 2002. What can economists learn from happiness research? Journal of Economic Literature 40, 402-435.

Frijters, P., Geishecker, I., Haisken-DeNew, J., Shields, M., 2006. Can the large swings in Russian life satisfaction be explained by the ups and downs in real incomes? Scandinavian Journal of Economics 108, 433-458.

Frijters, P., Haisken-DeNew, J., Shields, M., 2004a. Investigating the patterns and determinants of life satisfaction in Germany following reunification. The Journal of Human Resources 39, 649-674.

Frijters, P., Haisken-DeNew, J., Shields, M., 2004b. Money does matter! Evidence from increasing real income and life satisfaction in East Germany following reunification. American Economic Review 94, 730-740.

Frijters, P., van Praag, B., 1998. The effects of climate on welfare and well-being in Russia. Climatic Change 39, 61-81.

Gillard, Q., 1981. The effect of environmental amenities on house values: The example of a view lot. Professional Geographer 33, 166-220.

Graham, C., Eggers, A., Sukhtankar, S., 2004. Does happiness pay? An exploration based on panel data from Russia. Journal of Economic Behavior and Organization 55, 319-342.

Gray, M., de Vaus, D., Qu, L., Stanton, D., 2010. Divorce and the wellbeing of older Australians, Research Paper No. 46. Australian Institute of Family Studies, Canberra. 
Groothuis, P., Groothuis, J., Whitehead, J., 2007. The willingness to pay to remove billboards and improve scenic amenities. Journal of Environmental Management 85, 1094-1100.

Haisken-DeNew, J., 2001. A hitchhiker's guide to the world's household panel data sets. The Australian Economic Review 34, 356-366.

Hill, R., Griffiths, W., Lim, G., 2008. Principles of Econometrics, third ed. John Wiley \& Sons, New Jersey.

Jim, C., Chen, W., 2009. Value of scenic views: Hedonic assessment of private housing in Hong Kong. Landscape and Urban Planning 91, 226-234.

Koivumaa-Honkanen, H., Honkanen, R., Viinamaki, H., Heikkila, K., Kaprio, J., Koskenvuo, M., 2001. Life satisfaction and suicide: A 20-year follow-up study. American Journal of Psychiatry 158, 433-439.

Lepper, H., 1998. Use of other-reports to validate subjective well-being measures. Social Indicators Research 44, 367-379.

Levinson, A., 2009. Valuing public goods using happiness data: The case of air quality, National Bureau of Economic Research Working Paper No. 15156, Washington DC.

Luechinger, S., 2009. Valuing air quality using the life satisfaction approach. The Economic Journal 119, 482-515.

Luechinger, S., Raschky, P., 2009. Valuing flood disasters using the life satisfaction approach. Journal of Public Economics 93, 620-633.

MacKerron, G., Mourato, S., 2009. Life satisfaction and air quality in London. Ecological Economics 68, 1441-1453.

Margolis, R., Myrskyla, M., 2010. A global perspective on happiness and fertility, Working Paper No. 2010-025. Max Plank Institute for Demographic Research, Rostock.

McLeod, P., 1984. The demand for local amenity: An hedonic price analysis. Environment and Planning A 16, 389-400.

Moro, M., Brereton, F., Ferreira, S., Clinch, J., 2008. Ranking quality of life using subjective well-being data. Ecological Economics 65, 448-460.

Moulton, B., 1986. Random group effects and the precision of regression estimates. Journal of Econometrics 32, 385-397.

Moulton, B., 1990. An illustration of a pitfall in estimating the effects of aggregate variables on micro units. Review of Economics and Statistics 72, 334-338.

Nasar, J., Hong, X., 1999. Visual preferences in urban signscapes. Environment and Behavior 31, 671-691.

Newman, C., 2007. Lord Mayor opens landmark Brisbane event, Council Newsroom, Brisbane.

$\mathrm{Ng}, \mathrm{Y} ., 2008$. Happiness studies: Ways to improve comparability and some public policy implications. The Economic Record 84, 253-266.

Nichols, A., Schaffer, M., 2007. Clustered errors in Stata, Paper Presented at the United Kingdom Stata Users' Group Meeting, September 2007, London. 
Office of Economic and Statistical Research, 2010. Queensland regional profiles: SEQ region, Queensland Treasury, Brisbane.

Pearson, L., Tisdell, C., Lisle, A., 2002. The impact of Noosa National Park on surrounding property values: An application of the Hedonic Price Method. Economic Analysis and Policy 32, 155-171.

Queensland Department of Infrastructure and Planning, 2009. South East Queensland Regional Plan 2009-2031, Brisbane.

Randall, A., Ives, B., Eastman, C., 1974. Bidding games for valuation of aesthetic environmental improvements. Journal of Environmental Economics and Management 1, 132-149.

Ravallion, M., Lokshin, M., 2001. Identifying welfare effects from subjective questions. Economica 68, 335-357.

Rehdanz, K., 2007. Species diversity and human well-being: A spatial econometric approach, Working Paper No. FNU-151. Hamburg University Centre for Marine and Atmospheric Science, Hamburg.

Rehdanz, K., Maddison, D., 2005. Climate and happiness. Ecological Economics 52, 111-125.

Samarasinghe, O., Sharp, B., 2010. Flood prone risk and amenity values: A spatial hedonic analysis. Australian Journal of Agricultural and Resource Economics 54, 457-475.

Sandvik, E., Diener, E., Seidlitz, L., 1993. Subjective well-being: The convergence and stablity of self-report and non-self-report measures. Journal of Personality 61, 317-342.

Saucier, G., 1994. Mini-markers: A brief version of Goldberg's unipolar Big-Five markers. Journal of Personality Assessment 63, 506-516.

Schwarz, N., Strack, F., 1991. Context effects in attitude surveys: Applying cognitive theory to social research. European Review of Social Psychology 2, 31-50.

SEQ Regional Scenic Amenity Study, 2005. What's in a view?, Report 1: Overview of the Scenic SEQ 2004 Public Preference Survey, Brisbane.

Shields, M., Price, S., Wooden, M., 2009. Life satisfaction and the economic and social characteristics of neighbourhoods. Journal of Population Economics 22, 421-443.

Shields, M., Wooden, M., 2003. Marriage, children and subjective well-being, A paper presented to the Australian Institute of Family Studies conference, Melbourne.

Smith, V., 2008. Reflections on the literature. Review of Environmental Economics and Policy 2, 292-308.

Smyth, R., Mishra, V., Qian, X., 2008. The environment and well-being in urban China. Ecological Economics 68, 547-555.

Stiglitz, J., Sen, A., Fitoussi, J., 2008. Report by the Commission on the Measurement of Economic Performance and Social Progress, Paris.

Swanwick, C., 2002. Landscape character assessment: Guidance for England and Scotland, Working Paper No. 96 The Countryside Agency and Scottish Natural Heritage, Cheltenham. 
Tapsuwan, S., Ingram, G., Burton, M., Brennan, D., 2009. Capitalized amenity value of urban wetlands: A hedonic property price approach to urban wetlands in Perth, Western Australia. Australian Journal of Agricultural and Resource Economics 53, 527-545.

Ulrich, R., 1979. Visual landscapes and psychological well-being. Landscape Research 4, 1723.

van Praag, B., Baarsma, B., 2005. Using happiness surveys to value intangibles: The case of airport noise. Economic Journal 115, 224-246.

Veenhoven, R., 1993. Happiness in Nations: Subjective Appreciation of Life in 56 Nations. Erasmus University Press, Rotterdam.

Veenhoven, R., 1996. Developments in satisfaction research. Social Indicators Research 37, 1-46.

Velarde, M., Fry, G., Tveit, M., 2007. Health effects of viewing landscapes: Landscape types in environmental psychology. Urban Forestry \& Urban Greening 6, 199-212.

Vogler, S., 2010. Brisbane City Council to defy State Government order by approving West End high-rise, Courier Mail, Brisbane.

Watson, N., Wooden, M., 2010. The HILDA survey: Progress and future developments. The Australian Economic Review 43, 326-336.

Welsch, H., 2002. Preferences over prosperity and pollution: Environmental valuation based on happiness surveys. Kyklos 55, 473-494.

Welsch, H., 2006. Environment and happiness: Valuation of air pollution using life satisfaction data. Ecological Economics 58, 801-813.

Welsch, H., 2007. Environmental welfare analysis: A life satisfaction approach. Ecological Economics 62, 544-551.

Welsch, H., Kuhling, J., 2009. Using happiness data for environmental valuation: Issues and applications. Journal of Economic Surveys 23, 385-406.

Willis, K., Garrod, G., 1993. Valuing landscape: A contingent valuation approach. Journal of Environmental Management 37, 1-22.

Winklemann, L., Winklemann, R., 1998. Why are the unemployed so unhappy? Evidence from panel data. Economica 65, 1-15.

Wooden, M., Warren, D., Drago, R., 2009. Working time mismatch and subjective wellbeing. British Journal of Industrial Relations 47, 147-179.

Wooden, M., Watson, N., 2007. The HILDA survey and its contribution to economic and social research (so far). The Economic Record 83, 208-231. 


\begin{tabular}{|c|c|}
\hline Variable name & Definition \\
\hline Age & Age of respondent in years \\
\hline Age squared & Age of respondent in years squared \\
\hline Male & Dummy variable $=1$ if respondent is male \\
\hline ATSI & $\begin{array}{l}\text { Dummy variable = } 1 \text { if respondent is of Aboriginal and/or Torres Strait } \\
\text { Islander origin }\end{array}$ \\
\hline Immigrant English & $\begin{array}{l}\text { Dummy variable = } 1 \text { if respondent is born in a Main English Speaking } \\
\text { country (Main English speaking countries are: United Kingdom; New } \\
\text { Zealand; Canada; USA; Ireland; and South Africa) }\end{array}$ \\
\hline Immigrant non-English & $\begin{array}{l}\text { Dummy variable }=1 \text { if respondent is not born in Australia or a Main } \\
\text { English Speaking country }\end{array}$ \\
\hline Poor English & $\begin{array}{l}\text { Dummy variable = } 1 \text { if respondent speaks English either not well or not } \\
\text { at all }\end{array}$ \\
\hline Number of children & $\begin{array}{l}\text { Number of respondent's own resident children in respondent's } \\
\text { household at least } 50 \text { per cent of the time and number of own } \\
\text { children who usually live in a non-private dwelling but spend the rest } \\
\text { of the time mainly with the respondent }\end{array}$ \\
\hline Married & Respondent is legally married \\
\hline Defacto & Respondent is in a defacto relationship \\
\hline Separated & Respondent is separated \\
\hline Divorced & Respondent is divorced \\
\hline Widow & Respondent is a widow \\
\hline Lone parent & Dummy variable $=1$ if respondent is a lone parent \\
\hline Mild health condition & $\begin{array}{l}\text { Respondent has a long-term health condition, that is a condition that } \\
\text { has lasted or is likely to last for more than six months and this } \\
\text { condition does not limit the type or amount of work the respondent } \\
\text { can do }\end{array}$ \\
\hline Moderate health condition & $\begin{array}{l}\text { Respondent has a long-term health condition limiting the amount or } \\
\text { type of work that the respondent can do }\end{array}$ \\
\hline Severe health condition & Respondent has a long-term health condition and cannot work \\
\hline Year 12 & Respondent's highest level of education is Year 12 \\
\hline Certificate or diploma & Respondent's highest level of education is a certificate or diploma \\
\hline Bachelors degree or higher & $\begin{array}{l}\text { Respondent's highest level of education is a Bachelors degree or } \\
\text { higher }\end{array}$ \\
\hline Employed part-time & Respondent is employed and works less than 35 hours per week \\
\hline Self employed & Dummy variable $=1$ if the respondent is self employed. \\
\hline Unemployed & Respondent is not employed but is looking for work \\
\hline Retired & Respondent is retired \\
\hline Home duties & Respondent performs home duties \\
\hline Student & Respondent is a non-working student \\
\hline Non-participant & $\begin{array}{l}\text { Respondent falls into the other non-participant category including } \\
\text { individuals less than } 15 \text { years old at the end of the last financial year }\end{array}$ \\
\hline Household income (In) & Natural log of disposable household income \\
\hline
\end{tabular}


Extraversion

Agreeableness

Conscientiousness

Emotional stability

Openness to experience

Others present

Major city

Scenic amenity

Disaggregated scen

Low scenic amenity

Medium scenic amenity

High scenic amenity

Very high scenic amenity
Degree of extraversion (scale 1 to 7 )

Degree of agreeableness (scale 1 to 7 )

Degree of conscientiousness (scale 1 to 7 )

Degree of emotional stability (scale 1 to 7 )

Degree of openness to experience (scale 1 to 7 )

Dummy variable $=1$ if someone was present during the interview

Dummy variable $=1$ if respondent is considered to reside in a major city region as defined by the Australian Bureau of Statistics' Accessibility/Remoteness Index of Australia

Spatially weighted average scenic amenity score (scale 1 to 10)

Omitted cases are: Female; Not of indigenous origin; Country of birth Australia; Speaks English well or very well; Never married and not de facto; Not a lone parent; Does not have a long-term health condition; Year 11 or below; Not self employed (employee, employee of own business, unpaid family worker); Employed working 35 hours or more per week; No others present during the interview or don't know - telephone interview; Not in a major city; Very low scenic amenity (1-3). 
Table 2A: Model results (OLS)

\begin{tabular}{|c|c|c|c|}
\hline Variable name & $\begin{array}{l}\text { OLS estimate } \\
\text { (standard error) }\end{array}$ & Variable name & $\begin{array}{c}\text { OLS estimate } \\
\text { (standard error) }\end{array}$ \\
\hline Constant & $\begin{array}{l}4.0612 * * * \\
(0.8907)\end{array}$ & Year 12 & $\begin{array}{r}0.3357^{*} \\
(0.1771)\end{array}$ \\
\hline Age & $\begin{array}{l}-0.0372^{* *} \\
(0.0147)\end{array}$ & Certificate or diploma & $\begin{array}{l}-0.0753 \\
(0.0845)\end{array}$ \\
\hline Age squared & $\begin{array}{l}0.0005 * * * \\
(0.0002)\end{array}$ & $\begin{array}{l}\text { Bachelors degree or } \\
\text { higher }\end{array}$ & $\begin{array}{l}-0.1111 \\
(0.1014)\end{array}$ \\
\hline Male & $\begin{array}{c}0.0617 \\
(0.0695)\end{array}$ & Employed part-time & $\begin{array}{l}0.2045^{* *} \\
(0.0846)\end{array}$ \\
\hline ATSI & $\begin{array}{c}0.4641^{*} \\
(0.2654)\end{array}$ & Self employed & $\begin{array}{c}0.1508 \\
(0.1349)\end{array}$ \\
\hline Immigrant English & $\begin{array}{l}-0.2554^{* * *} \\
(0.0950)\end{array}$ & Unemployed & $\begin{array}{l}-0.0865 \\
(0.2365)\end{array}$ \\
\hline Immigrant non-English & $\begin{array}{l}-0.1370 \\
(0.1493)\end{array}$ & Retired & $\begin{array}{l}0.3871^{* *} \\
(0.1486)\end{array}$ \\
\hline Poor English & $\begin{array}{l}-0.8053 \\
(0.6485)\end{array}$ & Home duties & $\begin{array}{c}0.1830 \\
(0.1527)\end{array}$ \\
\hline Number of children & $\begin{array}{l}-0.0428 \\
(0.0400)\end{array}$ & Student & $\begin{array}{c}0.2966 \\
(0.1972)\end{array}$ \\
\hline Married & $\begin{array}{c}0.1239 \\
(0.1401)\end{array}$ & Non-participant & $\begin{array}{l}-0.3003 \\
(0.3714)\end{array}$ \\
\hline Defacto & $\begin{array}{c}0.1019 \\
(0.1297)\end{array}$ & Household income (In) & $\begin{array}{l}0.1607^{* *} \\
(0.0656)\end{array}$ \\
\hline Separated & $\begin{array}{l}-0.8554^{* *} \\
(0.3328)\end{array}$ & Extraversion & $\begin{array}{l}0.1266 * * * \\
(0.0330)\end{array}$ \\
\hline Divorced & $\begin{array}{l}-0.1030 \\
(0.1866)\end{array}$ & Agreeableness & $\begin{array}{l}0.2147 * * * \\
(0.0384)\end{array}$ \\
\hline Widow & $\begin{array}{l}-0.0117 \\
(0.2565)\end{array}$ & Conscientiousness & $\begin{array}{l}-0.0004 \\
(0.0307)\end{array}$ \\
\hline Lone parent & $\begin{array}{l}-0.1377 \\
(0.1436)\end{array}$ & Emotional stability & $\begin{array}{l}0.1386 * * * \\
(0.0329)\end{array}$ \\
\hline Mild health condition & $\begin{array}{l}-0.3084^{* *} \\
(0.1261)\end{array}$ & Openness to experience & $\begin{array}{l}-0.0011 \\
(0.0383)\end{array}$ \\
\hline Moderate health condition & $\begin{array}{l}-0.4423 * * * \\
(0.1062)\end{array}$ & Others present & $\begin{array}{c}0.0757 \\
(0.0685)\end{array}$ \\
\hline \multirow[t]{2}{*}{ Severe health condition } & $\begin{array}{l}-1.6958 * * * \\
(0.5071)\end{array}$ & Major city & $\begin{array}{c}0.0435 \\
(0.0943)\end{array}$ \\
\hline & & Scenic amenity & $\begin{array}{c}0.0413^{*} \\
(0.0212)\end{array}$ \\
\hline \multicolumn{4}{|l|}{ Summary statistics } \\
\hline Number of observations & \multicolumn{2}{|c|}{1630} & \\
\hline Adjusted $\mathrm{R}^{2}$ & \multicolumn{2}{|c|}{0.1518} & \\
\hline
\end{tabular}

*** significant at the $1 \%$ level; ** significant at the $5 \%$ level; * significant at the $10 \%$ level.

Omitted cases are: Female; Not of indigenous origin; Country of birth Australia; Speaks English well or very well; Never married and not de facto; Not a lone parent; Does not have a long-term health condition; Year 11 or below; Not self employed (employee, employee of own business, unpaid family worker); Employed working 35 hours or more per week; No others present during the interview or don't know - telephone interview; Not in a major city. 
Table 2B: Model results (ordered probit)

\begin{tabular}{|c|c|c|c|}
\hline Variable name & $\begin{array}{l}\text { Probit estimate } \\
\text { (standard error) }\end{array}$ & Variable name & $\begin{array}{l}\text { Probit estimate } \\
\text { (standard error) }\end{array}$ \\
\hline Age & $\begin{array}{l}-0.0323 * * * \\
(0.0121)\end{array}$ & Certificate or diploma & $\begin{array}{l}-0.0789 \\
(0.0736)\end{array}$ \\
\hline Age squared & $\begin{array}{l}0.0004 * * * \\
(0.0001)\end{array}$ & $\begin{array}{l}\text { Bachelors degree or } \\
\text { higher }\end{array}$ & $\begin{array}{l}-0.1032 \\
(0.0813)\end{array}$ \\
\hline Male & $\begin{array}{l}0.0669 \\
(0.0607)\end{array}$ & Employed part-time & $\begin{array}{l}0.2015 * * * \\
(0.0703)\end{array}$ \\
\hline ATSI & $\begin{array}{l}0.4753^{* *} \\
(0.2305)\end{array}$ & Self employed & $\begin{array}{c}0.1226 \\
(0.1111)\end{array}$ \\
\hline Immigrant English & $\begin{array}{l}-0.2094 * * * \\
(0.0769)\end{array}$ & Unemployed & $\begin{array}{l}-0.0320 \\
(0.1813)\end{array}$ \\
\hline Immigrant non-English & $\begin{array}{l}-0.0967 \\
(0.1164)\end{array}$ & Retired & $\begin{array}{l}0.3419 * * * \\
(0.1200)\end{array}$ \\
\hline Poor English & $\begin{array}{l}-0.7406 \\
(0.5414)\end{array}$ & Home duties & $\begin{array}{l}0.2551^{* *} \\
(0.1251)\end{array}$ \\
\hline Number of children & $\begin{array}{l}-0.0411 \\
(0.0350)\end{array}$ & Student & $\begin{array}{c}0.2594 \\
(0.1708)\end{array}$ \\
\hline Married & $\begin{array}{c}0.0865 \\
(0.1169)\end{array}$ & Non-participant & $\begin{array}{l}-0.1186 \\
(0.2866)\end{array}$ \\
\hline Defacto & $\begin{array}{c}0.0719 \\
(0.1073)\end{array}$ & Household income (In) & $\begin{array}{l}0.1314^{* *} \\
(0.0509)\end{array}$ \\
\hline Separated & $\begin{array}{l}-0.6209 * * * \\
(0.2316)\end{array}$ & Extraversion & $\begin{array}{l}0.1149 * * * \\
(0.0280)\end{array}$ \\
\hline Divorced & $\begin{array}{l}-0.0927 \\
(0.1516)\end{array}$ & Agreeableness & $\begin{array}{l}0.1939 * * * \\
(0.0340)\end{array}$ \\
\hline Widow & $\begin{array}{l}-0.0053 \\
(0.2106)\end{array}$ & Conscientiousness & $\begin{array}{l}0.0088 \\
(0.0256)\end{array}$ \\
\hline Lone parent & $\begin{array}{l}-0.0916 \\
(0.1210)\end{array}$ & Emotional stability & $\begin{array}{l}0.1143^{* * *} \\
(0.0270)\end{array}$ \\
\hline Mild health condition & $\begin{array}{l}-0.2368^{* *} \\
(0.1021)\end{array}$ & Openness to experience & $\begin{array}{l}-0.0099 \\
(0.0307)\end{array}$ \\
\hline Moderate health condition & $\begin{array}{l}-0.3484^{* * *} \\
(0.0826)\end{array}$ & Others present & $\begin{array}{c}0.0591 \\
(0.0604)\end{array}$ \\
\hline Severe health condition & $\begin{array}{l}-1.3433^{* * *} \\
(0.3871)\end{array}$ & Major city & $\begin{array}{l}0.0416 \\
(0.0851)\end{array}$ \\
\hline Year 12 & $\begin{array}{c}0.2797^{*} \\
(0.1566)\end{array}$ & Scenic amenity & $\begin{array}{l}0.0391^{* *} \\
(0.0194)\end{array}$ \\
\hline \multicolumn{4}{|l|}{ Summary statistics } \\
\hline Number of observations & \multicolumn{2}{|c|}{1630} & \\
\hline Likelihood ratio & \multicolumn{2}{|c|}{-2530.98} & \\
\hline Pseudo $\mathrm{R}^{2}$ & \multicolumn{2}{|c|}{0.0572} & \\
\hline
\end{tabular}


Table 3: Value estimates (AUD \$ household income per annum)

\begin{tabular}{lccccccc}
\hline & & \multicolumn{2}{c}{ OLS } & \multicolumn{3}{c}{ Ordered probit } \\
& $\begin{array}{l}\text { Point } \\
\text { estimate }\end{array}$ & \multicolumn{2}{c}{$\mathbf{9 0 \% \text { interval estimates }}$} & \multicolumn{2}{c}{$\begin{array}{c}\text { Point } \\
\text { estimate }\end{array}$} & \multicolumn{2}{c}{$\mathbf{9 0 \% \text { interval estimates }}$} \\
& & Lower & Upper & & Lower & Upper \\
\hline Willingness-to-pay & $\$ 12,673.81$ & $\$ 1,885.10$ & $\$ 23,462.52$ & $\$ 14,699.92$ & $\$ 2,729.46$ & $\$ 26,670.38$ \\
Compensating surplus & $\$ 15,171.55$ & $\$ 2,623.95$ & $\$ 24,350.63$ & $\$ 17,121.05$ & $\$ 3,753.56$ & $\$ 26,570.73$ \\
Equivalent surplus & $\$ 21,903.49$ & $\$ 2,771.26$ & $\$ 48,056.85$ & $\$ 26,212.59$ & $\$ 4,062.47$ & $\$ 57,546.07$ \\
\hline
\end{tabular}


Table 4: WTP income effect estimates (\$AUD household income per annum)

\begin{tabular}{lrc}
\hline & \multicolumn{1}{c}{ OLS } & Ordered probit \\
\hline WTP $25^{\text {th }}$ Percentile & $\$ 9,614.78$ & $\$ 11,196.48$ \\
WTP Median & $\$ 13,689.41$ & $\$ 15,870.42$ \\
WTP $75^{\text {th }}$ Percentile & $\$ 16,305.57$ & $\$ 18,871.38$ \\
\hline
\end{tabular}


Table 5: Model results (OLS and ordered probit)

\begin{tabular}{|c|c|c|}
\hline Variable name & $\begin{array}{l}\text { OLS estimate } \\
\text { (standard error) }\end{array}$ & $\begin{array}{l}\text { Ordered probit estimate } \\
\text { (standard error) }\end{array}$ \\
\hline $\begin{array}{l}\text { Low level of scenic amenity } \\
\left(3<a_{i, k} \leq 4\right)\end{array}$ & $\begin{array}{l}0.3006^{* *} \\
(0.1256)\end{array}$ & $\begin{array}{l}0.2886^{* * *} \\
(0.1038)\end{array}$ \\
\hline $\begin{array}{l}\text { Medium level of scenic amenity } \\
\left(4<a_{i, k} \leq 7\right)\end{array}$ & $\begin{array}{l}0.3129 * * \\
(0.1264)\end{array}$ & $\begin{array}{l}0.2913 * * * \\
(0.1043)\end{array}$ \\
\hline $\begin{array}{l}\text { High level of scenic amenity } \\
\left(7<a_{i, k} \leq 8\right)\end{array}$ & $\begin{array}{l}0.3396^{* *} \\
(0.1595)\end{array}$ & $\begin{array}{l}0.3289 * * \\
(0.1400)\end{array}$ \\
\hline $\begin{array}{l}\text { Very high level of scenic amenity } \\
\left(8<a_{i, k} \leq 10\right)\end{array}$ & $\begin{array}{l}0.6913^{* * *} \\
(0.1554)\end{array}$ & $\begin{array}{l}0.6393^{* * *} \\
(0.1460)\end{array}$ \\
\hline \multicolumn{3}{|l|}{ Summary Statistics } \\
\hline Number of observations & & 1630 \\
\hline Adjusted $R^{2}$ & & \\
\hline Likelihood ratio & & -2526.9005 \\
\hline Pseudo $\mathrm{R}^{2}$ & & 0.0587 \\
\hline
\end{tabular}

*** significant at the $1 \%$ level; ** significant at the $5 \%$ level; * significant at the $10 \%$ level.

Omitted case: Very low level of scenic amenity $\left(1 \leq a_{i, k} \leq 3\right)$. 
Table 6: WTP to improve level of scenic amenity (OLS / ordered probit) - \$AUD household income per annum

\begin{tabular}{|c|c|c|c|c|}
\hline & Low & Medium & High & Very high \\
\hline Move from very low to: & $\$ 92,667.93 / \$ 88,953.42$ & $\$ 96,446.22 / \$ 89,800.70$ & $\$ 104,670.52 / \$ 101,368.98$ & $\$ 213,088.70 / \$ 197,072.48$ \\
\hline Move from low to: & & $\$ 3,778.29 / \$ 847.28$ & $\$ 12,002.59 / \$ 12,415.57$ & $\$ 120,420.76 / \$ 108,119.06$ \\
\hline Move from medium to: & & & $\$ 8,224.30 / \$ 11,568.29$ & $\$ 116,642.48 / \$ 107,271.78$ \\
\hline Move from high to: & & & & $\$ 108,418.17 / \$ 95,703.50$ \\
\hline
\end{tabular}


Figure 1: South East Queensland

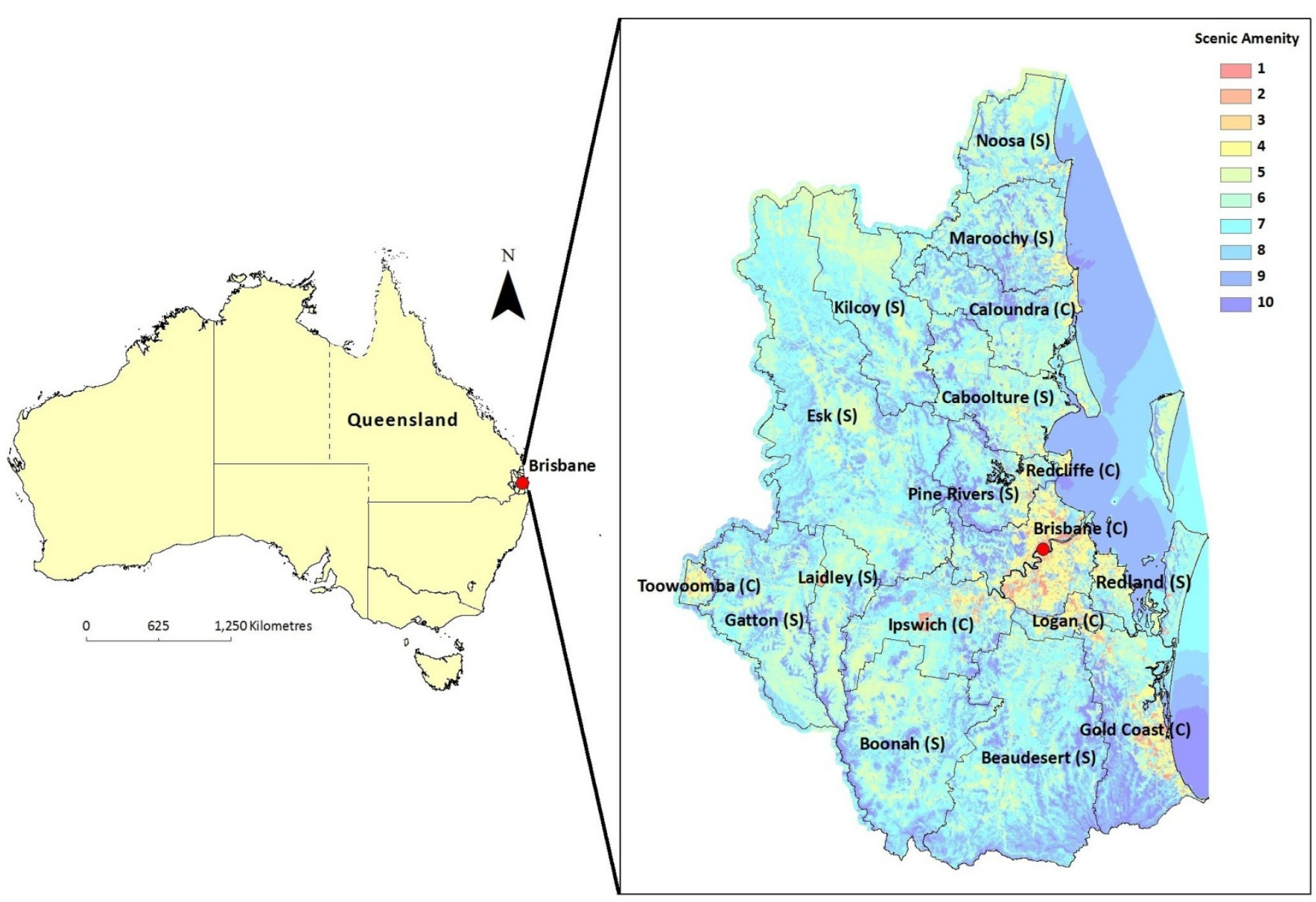

Source: SEQ Regional Scenic Amenity Study (2005) 
Figure 2: Stages in assessing scenic amenity

Stage 1

Stage 2

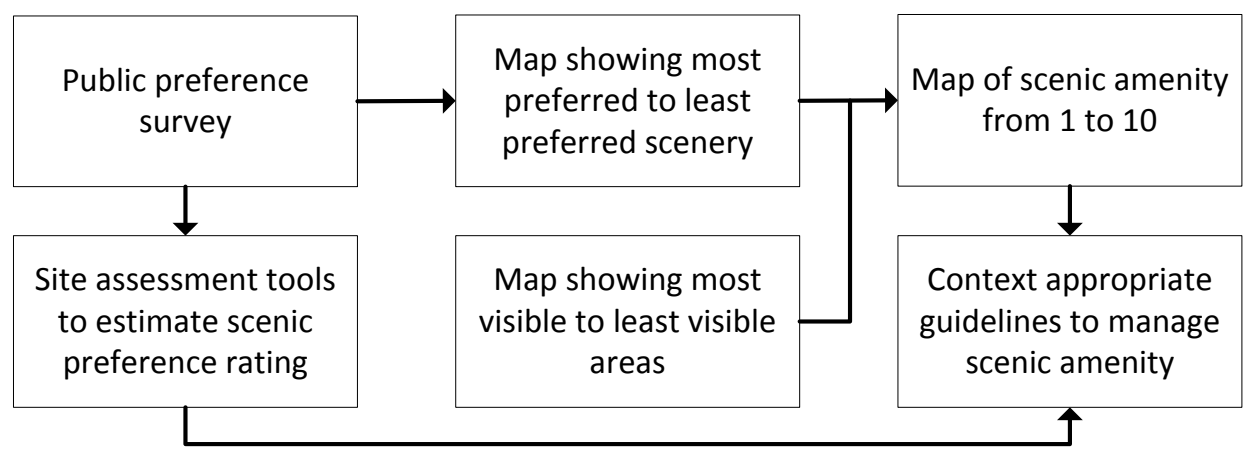

Source: SEQ Regional Scenic Amenity Study (2005) 